\title{
Crystal Structure of a Novel Proton-Transfer Compound: Ethylenediguanidinium Pyridine-2,6-dicarboxylate Trihydrate
}

\author{
Abolghasem Moghimi, ${ }^{* 1}$ Hossein Aghabozorg, ${ }^{* 2, \dagger}$ Shabnam SheshmanI, ${ }^{* 3}$ Guido KICKelbick, ${ }^{* 4}$ and \\ Janet SOLEIMANNEJAD $* 5$
}

*1 Department of Chemistry, Imam Hossein University, Tehran, Iran

*2 Department of Chemistry, Teacher Training University, Tehran, Iran

*3 Department of Chemistry, Islamic Azad University, Shahr-e Rey Branch, Tehran, Iran

*4 Institute of Materials Chemistry, Vienna University of Technology, Wien, Austria

*5 Department of Chemistry, Faculty of Science, Ilam University, Ilam, Iran

\begin{abstract}
A proton-transfer compound, $\left(\mathrm{EDGH}_{2}\right)(\mathrm{pydc}) \cdot 3 \mathrm{H}_{2} \mathrm{O}$, was synthesized from the reaction of 2,6-pyridinedicarboxylic acid, pydcH $\mathrm{H}_{2}$, and ethylenediguanidine, EDG. The crystal structure was determined by single-crystal X-ray diffraction. This compound crystallized in the space group $P \overline{1}$ of the triclinic system and contained two molecules per unit-cell. The unitcell parameters were: $a=7.798(1) \AA, b=10.806(2) \AA, c=10.829(2) \AA$, with $\alpha=102.462(2)^{\circ}, \beta=104.433(2)^{\circ}$, and $\gamma=$ $96.094(2)^{\circ}$. The final $R$ value was 0.0573 for 3484 measured reflections.
\end{abstract}

(Received May 18, 2005; Accepted July 20, 2005; Published on web September 30, 2005)

Molecular self-association involves the spontaneous association of molecules into stable aggregates, joined by ion-pairing, hydrogen bonding, $\pi$ - $\pi$ stacking and donor-acceptor interactions. In an ideal case, one or combination of some of these noncovalent interactions processes may result in the formation of a specific and spontaneous self-associated form of the desired aggregate. ${ }^{1}$ Our research group recently focused on the synthesis of watersoluble proton-transfer compounds that can function as suitable ligands in the synthesis of metal-organo complexes. In connection with this research area, we have already selected 2,6-pyridinedicarboxylic acid, pydcH $\mathrm{H}_{2}$, and 1,10-phenanthroline-2,9-dicarboxylic acid, phendcH $\mathrm{H}_{2}$, as proton donors and 2,6-pyridinediamine, pyda, guanidine, G, and 1,10-phenanthroline, phen, as proton acceptors. The proton-transfer process resulted in the formation of several compounds: $\left(\right.$ pydaH $\left._{2}\right)($ phendc $),{ }^{2} \quad(\mathrm{GH})_{2}($ pydc $),{ }^{3}$ $(\text { phenH })_{2}($ pydc $){ }^{4}$ Here, we wish to report on the molecular and crystal structures of a novel proton-transfer compound obtained from the reaction between 2,6-pyridinedicarboxylic acid, pydcH $_{2}$, and ethylenediguanidine, EDG.

Thiourea $(8.48 \mathrm{~g}, 0.112 \mathrm{~mol})$ was slowly added to diethyl

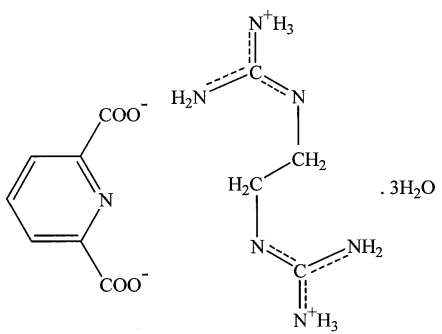

Fig. 1 Chemical structure of the title compound.

† To whom correspondence should be addressed.

E-mail: haghabozorg@yahoo.com sulfate $(7.2 \mathrm{~mL}, 0.056 \mathrm{~mol})$, and ethylisothioureanium sulfate was obtained. Then, to a solution of ethyl isothioureanium

Table 1 Crystal and experimental data for $\left(\mathrm{EDGH}_{2}\right)$ (pydc) $3 \mathrm{H}_{2} \mathrm{O}$

\section{Formula: $\mathrm{C}_{11} \mathrm{H}_{17} \mathrm{~N}_{7} \mathrm{O}_{7}$}

Formula weight $=359.32$

Crystal system: triclinic

Space group: $P \overline{1} \quad Z=2$

$a=7.798(1) \AA \quad \alpha=102.462(2)^{\circ}$

$b=10.806(2) \AA \quad \beta=104.433(2)^{\circ}$

$c=10.829(2) \AA \quad \gamma=96.094(2)^{\circ}$

$V=850.4(2) \AA^{3}$

$D_{\mathrm{x}}=1.403 \mathrm{~g} / \mathrm{cm}^{3}$

Crystal dimensions $\left(\mathrm{mm}^{3}\right): 0.78 \times 0.74 \times 0.24$

$T=296 \mathrm{~K}$

No. of reflection used $=3484$

No. of parameters $=229$

$\theta$ range for data collection $=2.43$ to $28.32^{\circ}$ Mo $K_{\alpha}(\lambda=0.71073$ $\AA$ )

$R_{1}=0.0573[I>2 \sigma(I)]$

$w R_{2}=0.1729$

Goodness-of-fit $=1.049$

$(\Delta / \sigma)_{\max }=0.042$

$(\Delta \rho)_{\max }=0.541 \mathrm{e}^{-3}$

$(\Delta \rho)_{\min }=-0.477 \mathrm{e}^{-3}$

Adsorption coefficient $=0.118 \mathrm{~mm}^{-1}$

$F\left(\begin{array}{lll}0 & 0 & 0\end{array}\right)=376$

Measurment: Siemens SMART CCD Detector

Program systems: SMART and SAINT

Structure determination: direct method

Refinement: full-matrix least-square of $F^{2}$

CCDC 271301 contains the supplementary crystallographic data for this paper. These data can be obtained free of charge from The Cambridge Crystallographic Data Center. 
Table 2 Selected bond lengths $(\AA)$, bond angles $\left({ }^{\circ}\right)$ and torsion angles $\left({ }^{\circ}\right)$ for $\left(\mathrm{EDGH}_{2}\right)($ pydc $) \cdot 3 \mathrm{H}_{2} \mathrm{O}$

\begin{tabular}{lrll}
\hline $\mathrm{O}(8)-\mathrm{C}(7)$ & $1.260(2)$ & $\mathrm{C}(14)-\mathrm{N}(15)$ & $1.322(2)$ \\
$\mathrm{O}(9)-\mathrm{C}(7)$ & $1.241(2)$ & $\mathrm{C}(14)-\mathrm{N}(16)$ & $1.330(2)$ \\
$\mathrm{O}(11)-\mathrm{C}(10)$ & $1.236(2)$ & $\mathrm{C}(17)-\mathrm{N}(16)$ & $1.453(2)$ \\
$\mathrm{O}(12)-\mathrm{C}(10)$ & $1.252(2)$ & $\mathrm{C}(17)-\mathrm{C}(17 \mathrm{~A})$ & $1.516(4)$ \\
$\mathrm{N}(1)-\mathrm{C}(2)$ & $1.341(2)$ & $\mathrm{C}(19)-\mathrm{N}(18)$ & $1.321(2)$ \\
$\mathrm{N}(1)-\mathrm{C}(6)$ & $1.339(2)$ & $\mathrm{C}(19)-\mathrm{N}(20)$ & $1.332(2)$ \\
$\mathrm{C}(2)-\mathrm{C}(7)$ & $1.522(2)$ & $\mathrm{C}(19)-\mathrm{N}(21)$ & $1.328(2)$ \\
$\mathrm{C}(6)-\mathrm{C}(10)$ & $1.519(2)$ & $\mathrm{C}(22)-\mathrm{N}(21)$ & $1.449(2)$ \\
$\mathrm{C}(14)-\mathrm{N}(13)$ & $1.334(2)$ & $\mathrm{C}(22)-\mathrm{C}(22 \mathrm{~A})$ & $1.526(3)$ \\
& & & \\
$\mathrm{C}(2)-\mathrm{N}(1)-\mathrm{C}(6)$ & $118.33(13)$ & $\mathrm{N}(1)-\mathrm{C}(6)-\mathrm{C}(10)$ & $117.08(13)$ \\
$\mathrm{O}(8)-\mathrm{C}(7)-\mathrm{O}(9)$ & $125.15(16)$ & $\mathrm{C}(5)-\mathrm{C}(6)-\mathrm{C}(10)$ & $120.44(14)$ \\
$\mathrm{O}(8)-\mathrm{C}(7)-\mathrm{C}(2)$ & $117.01(14)$ & $\mathrm{N}(13)-\mathrm{C}(14)-\mathrm{N}(15)$ & $120.93(16)$ \\
$\mathrm{O}(9)-\mathrm{C}(7)-\mathrm{C}(2)$ & $117.85(15)$ & $\mathrm{N}(13)-\mathrm{C}(14)-\mathrm{N}(16)$ & $117.89(16)$ \\
$\mathrm{N}(1)-\mathrm{C}(2)-\mathrm{C}(3)$ & $122.62(14)$ & $\mathrm{N}(15)-\mathrm{C}(14)-\mathrm{N}(16)$ & $121.16(16)$ \\
$\mathrm{N}(1)-\mathrm{C}(2)-\mathrm{C}(7)$ & $116.24(13)$ & $\mathrm{C}(14)-\mathrm{N}(16)-\mathrm{C}(17)$ & $124.04(14)$ \\
$\mathrm{C}(3)-\mathrm{C}(2)-\mathrm{C}(7)$ & $121.14(14)$ & $\mathrm{N}(18)-\mathrm{C}(19)-\mathrm{N}(20)$ & $121.02(15)$ \\
$\mathrm{O}(11)-\mathrm{C}(10)-\mathrm{O}(12)$ & $125.31(15)$ & $\mathrm{N}(18)-\mathrm{C}(19)-\mathrm{N}(21)$ & $121.62(15)$ \\
$\mathrm{O}(11)-\mathrm{C}(10)-\mathrm{C}(6)$ & $118.27(14)$ & $\mathrm{N}(20)-\mathrm{C}(19)-\mathrm{N}(21)$ & $117.36(15)$ \\
$\mathrm{O}(12)-\mathrm{C}(10)-\mathrm{C}(6)$ & $116.41(14)$ & $\mathrm{C}(19)-\mathrm{N}(21)-\mathrm{C}(22)$ & $124.10(14)$ \\
$\mathrm{N}(1)-\mathrm{C}(6)-\mathrm{C}(5)$ & $122.48(14)$ & & \\
& & & \\
$\mathrm{O}(8)-\mathrm{C}(7)-\mathrm{C}(2)-\mathrm{N}(1)$ & $3.3(2)$ & $\mathrm{O}(11)-\mathrm{C}(10)-\mathrm{C}(6)-\mathrm{N}(1)$ & $-17.7(2)$ \\
$\mathrm{O}(9)-\mathrm{C}(7)-\mathrm{C}(2)-\mathrm{N}(1)$ & $-176.2(2)$ & $\mathrm{O}(12)-\mathrm{C}(10)-\mathrm{C}(6)-\mathrm{N}(1)$ & $162.2(2)$ \\
$\mathrm{O}(8)-\mathrm{C}(7)-\mathrm{C}(2)-\mathrm{C}(3)$ & $-176.0(2)$ & $\mathrm{O}(11)-\mathrm{C}(10)-\mathrm{C}(6)-\mathrm{C}(5)$ & $161.4(2)$ \\
$\mathrm{O}(9)-\mathrm{C}(7)-\mathrm{C}(2)-\mathrm{C}(3)$ & $4.5(2)$ & $\mathrm{O}(12)-\mathrm{C}(10)-\mathrm{C}(6)-\mathrm{C}(5)$ & $-18.7(2)$ \\
& & & \\
\hline
\end{tabular}

sulfate $(12.32 \mathrm{~g}, 0.04 \mathrm{~mol})$ in water $(30 \mathrm{~mL})$ was added ethylenediamine $(2.24 \mathrm{~g}, 0.04 \mathrm{~mol})$, and ethylenediguanidine sulfate was filtered off. After the addition of sodium hydroxide $(0.80 \mathrm{~g}, 0.02 \mathrm{~mol})$ to ethylenediguanidine sulfate $(3.42 \mathrm{~g}, 0.01$ $\mathrm{mol})$ in ethanol $(10 \mathrm{~mL}), 2,6$-pyridinedicarboxylic acid $(1.67 \mathrm{~g}$, $0.01 \mathrm{~mol}$ ) was added to the filtrate and the reaction mixture was stirred at $60{ }^{\circ} \mathrm{C}$ for $1 \mathrm{~h}$. After two days, crystals of the protontransfer, $\left(\mathrm{EDGH}_{2}\right)\left(\right.$ pydc) $\cdot 3 \mathrm{H}_{2} \mathrm{O}$, were obtained. mp, $240-241{ }^{\circ} \mathrm{C}$. ${ }^{1} \mathrm{H}$ NMR $\left(\mathrm{D}_{2} \mathrm{O}\right.$ and trace $\left.\mathrm{CD}_{3} \mathrm{COCD}_{3}\right): \delta=8.0$ (H-pydc), 4.6(NH), 3.4 $\left(\mathrm{CH}_{2}\right) \mathrm{ppm} .{ }^{13} \mathrm{C} \mathrm{NMR}\left(\mathrm{D}_{2} \mathrm{O}\right.$ and trace $\left.\mathrm{CD}_{3} \mathrm{COCD}_{3}\right)$ : $\delta=172.2$ (C-pydc), $156.8\left(\mathrm{C}-\mathrm{DGH}_{2}\right), 152.6$ (C-pydc), 138.3 (C-pydc), 124.8 (C-pydc), $39.8\left(\mathrm{C}-\mathrm{CH}_{2}\right) \mathrm{ppm}$.

The crystal and experimental data are listed in Table 1. The data were corrected for polarization and Lorentz effects, and an empirical absorption correction (SADABS) was applied. ${ }^{5}$ The cell dimensions were refined with all unique reflections. The structure was solved by direct methods (SHELXS-97). ${ }^{6}$ Refinement was carried out with the full-matrix least-squares method based on $F^{2}$ (SHELXL-97) with anisotropic thermal parameters for all non-hydrogen atoms. Hydrogen atoms were inserted in calculated positions and refined riding with the corresponding atom. Selected bond distances, bond angles and torsion angles are given in Table 3. Selected intermolecular hydrogen bond distances are listed in Table 4. The numbering scheme as well as an ORTEP drawing is shown in Fig. 2.

With respect to the presented X-ray crystal structure, the proton-transfer compound was composed of $\left(\mathrm{EDGH}_{2}\right)^{2+}$ and

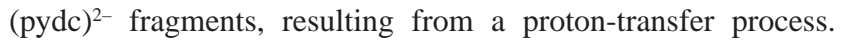
The presented results indicate that the reaction between 2,6pyridinedicarboxylic acid and ethylenediguanidine resulted in the transfer of two carboxylic acid protons to the one ethylenediguanidine molecule (Fig. 2). The three $\mathrm{C}-\mathrm{N}$ bond lengths in each of $\mathrm{CN}_{3}$ groups are very close in values (Table 3 ). These bond distances are intermediate between $\mathrm{C}-\mathrm{N}$ and $\mathrm{C}=\mathrm{N}$ bonds. The average $\mathrm{CN}$ bond distance in $\mathrm{C}(14) \mathrm{N}_{3}$ and $\mathrm{C}(19) \mathrm{N}_{3}$ groups are 1.328 and $1.327 \AA$ respectively, which is significantly shorter than the $\mathrm{C}(17)-\mathrm{N}(16)$ and $\mathrm{C}(22)-\mathrm{N}(21)$ bond distances (Table 3). The summation of bond angles in the $\mathrm{C}(14) \mathrm{N}_{3}$ and $\mathrm{C}(19) \mathrm{N}_{3}$ groups are 359.98 and $360.00^{\circ}$, respectively, which

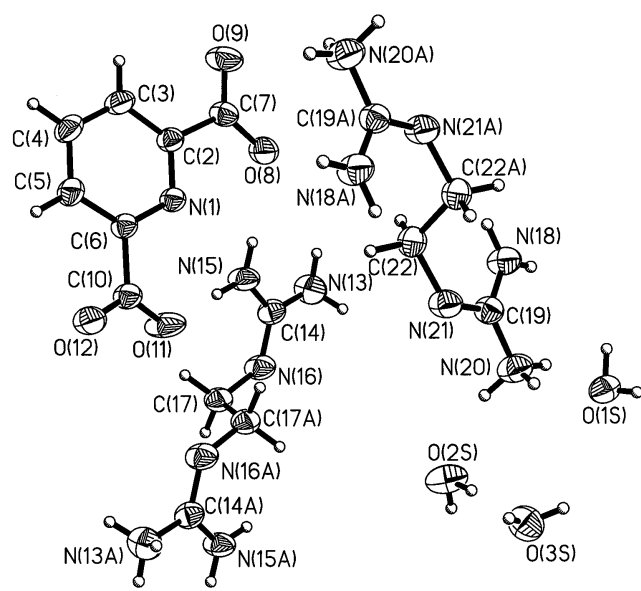

Fig. 2 The molecular structure of $\left(\mathrm{EDGH}_{2}\right)(\mathrm{pydc}) \cdot 3 \mathrm{H}_{2} \mathrm{O}$

Table 3 Selected hydrogen bonds for $\left(\mathrm{EDGH}_{2}\right)(\mathrm{pydc}) \cdot 3 \mathrm{H}_{2} \mathrm{O}$

\begin{tabular}{crrrrl}
\hline $\mathrm{D}-\mathrm{H}$ & $\mathrm{d}(\mathrm{D}-\mathrm{H})$ & $\mathrm{d}(\mathrm{H} \cdots \mathrm{A})$ & $\mathrm{d}(\mathrm{D} \cdots \mathrm{A})$ & $\angle \mathrm{DHA}$ & \multicolumn{1}{c}{$\mathrm{A}$} \\
\hline $\mathrm{N}(13)-\mathrm{H}(13 \mathrm{C})$ & 0.89 & 2.16 & $2.946(2)$ & 147.5 & $\mathrm{O}(3 \mathrm{~S})^{\mathrm{a}}$ \\
$\mathrm{N}(15)-\mathrm{H}(15 \mathrm{~A})$ & 0.86 & 2.10 & $2.931(2)$ & 163.0 & $\mathrm{O}(11)$ \\
$\mathrm{N}(18)-\mathrm{H}(18 \mathrm{~A})$ & 0.86 & 2.11 & $2.949(2)$ & 163.5 & $\mathrm{O}(2 \mathrm{~S})^{\mathrm{b}}$ \\
$\mathrm{N}(18)-\mathrm{H}(18 \mathrm{~B})$ & 0.86 & 1.95 & $2.806(2)$ & 174.1 & $\mathrm{O}(12)^{\mathrm{c}}$ \\
$\mathrm{N}(20)-\mathrm{H}(20 \mathrm{~B})$ & 0.89 & 2.12 & $2.953(2)$ & 154.6 & $\mathrm{O}(1 \mathrm{~S})$ \\
$\mathrm{N}(15)-\mathrm{H}(15 \mathrm{~B})$ & 0.86 & 2.16 & $3.005(2)$ & 166.4 & $\mathrm{O}(8)$ \\
\hline
\end{tabular}

$\mathrm{a}: x, y-1, z ; \mathrm{b}:-x+1,-y+1,-z+1 ; \mathrm{c}: x, y, z-1$.

indicates that each $\mathrm{CN}_{3}$ unit in the cation adopts a planar structure. The carboxylate groups are differently oriented $[\mathrm{N}(1)-\mathrm{C}(2)-\mathrm{C}(7)-\mathrm{O}(8): 3.3(2) ; \mathrm{N}(1)-\mathrm{C}(2)-\mathrm{C}(7)-\mathrm{O}(9)$ : $-176.2(2)$; $\mathrm{N}(1)-\mathrm{C}(6)-\mathrm{C}(10)-\mathrm{O}(11)$ : $-17.7(2)$; and $\mathrm{N}(1)-\mathrm{C}(6)-\mathrm{C}(10)-\mathrm{O}(12)$ : $\left.162.2(2)^{\circ}\right]$ with a more marked torsion for $\mathrm{N}(1) \cdots \mathrm{O}(11)(-17.7(2))$ and $\mathrm{N}(1) \cdots \mathrm{O}(12)\left(162.2(2)^{\circ}\right)$ due to H-bonds (Table 4). The most important features of the crystal structure of $\left(\mathrm{EDGH}_{2}\right)\left(\right.$ pydc) $\cdot 3 \mathrm{H}_{2} \mathrm{O}$ are the interactions between $\left(\mathrm{EDGH}_{2}\right)^{2+}$ and (pydc) $)^{2-}$ fragments consisting of ion-pairing, and hydrogen bonding. In addition, the $\pi-\pi$ stacking is between the anionanion fragments, and the interplanar distance is $3.34 \AA$.

\section{References}

1. J. A. Zerkowski, C. T. Seto, and G. M. Whitesides, J. Am. Chem. Soc., 1992, 114, 5473.

2. A. Moghimi, R. Alizadeh, A. Shokrollahi, H. Aghabozorg, M. Shamsipur, and A. Shockravi, Inorg. Chem., 2003, 42, 1616.

3. A. Moghimi, S. Sheshmani, A. Shokrollahi, H. Aghabozorg, M. Shamsipur, G. Kickelbick, M. Carla Aragoni, and V. Lippolis, Z. Anorg. Allg. Chem., 2004, 630, 617.

4. A. Moghimi, S. Sheshmani, A. Shokrollahi, M. Shamsipur, G. Kickelbick, and H. Aghabozorg, Z. Anorg. Allg. Chem., 2005, 631, 160.

5. G. M. Sheldrick, SADABS. University of Göttingen, Germany, 1996.

6. G. M. Sheldrick, SHELXS97 and SHELXL 97. University of Göttingen, Germany, 1997. 